\title{
Hallmark of success: top 50 classics in oral and maxillofacial cone-beam computed tomography
}

\author{
Yuhao Wu ${ }^{1,2 A, B, C, D, E, F}$, Haaris Tiwana ${ }^{3 B, C, D}$, Mariyam Durrani ${ }^{4 A, C}$, Sabeen Tiwana ${ }^{5 A, C, D, E}$, Bo Gong ${ }^{1,2 C, D, E}$, \\ Kashif Hafeez ${ }^{6 A, D, E}$, Faisal Khosa ${ }^{1 A, B}$ \\ 'Department of Radiology, Vancouver General Hospital, University of British Columbia, Vancouver, BC, Canada \\ 2Undergraduate Program, Faculty of Medicine, University of British Columbia, Vancouver, BC, Canada \\ ${ }^{3}$ BDS Program, Lahore Medical and Dental College, Lahore, Pakistan \\ ${ }^{4}$ Faculty of Medicine, Masaryk University, Kamenice, Brno, Czech Republic \\ ${ }^{5}$ Faculty of Dentistry, University of British Columbia, Vancouver, BC, Canada \\ ${ }^{6}$ Easton Dental Practice, Bristol, United Kingdom
}

\section{Abstract}

Purpose: The aim of this study was to identify the top 50 cited articles on the use of cone-beam computed tomography (CBCT) for oral and maxillofacial applications and to summarise the characteristics of the most impactful research articles in this domain.

Material and methods: A database was generated by combining the search results from Thomson Reuters Web of Science and Elsevier's Scopus to ensure that all top-cited publications were captured. We used three search fields to generate the database: 1) CBCT, 2) oral and maxillofacial pathologies, and 3) oral and maxillofacial anatomical structures. Publications were then ranked by citation counts and reviewed by two independent reviewers.

Results: A total of 50 top publications were included in the study. Their citation count ranged from 43 to 170 with a median of 55.5. Five publications were cited more than 100 times. All except for one paper were published after 2000. The most well published journal was the American Journal of Orthodontics and Dentofacial Orthopedics $(n=12)$, and the United States of America $(n=15)$ was the most productive country in the field. The majority of the studies $(n=27)$ discussed the imaging of primary tooth pathologies, but there are also a significant number of articles that discuss imaging of bone grafts or dental implants $(n=7)$, upper airways $(n=5)$, the skull $(n=4)$, and other maxillofacial structures $(n=7)$.

Conlcusions: Our study identifies 50 research articles with the highest number of citations in oral and maxillofacial CBCT, discusses the characteristics and commonalities between these articles, and predicts future trends in the field.

Key words: bibliometrics, cone-beam computed tomography, dentistry, maxillofacial abnormalities.

\section{Introduction}

Cone-beam computed tomography $(\mathrm{CBCT})$ is a relatively recent technology, which can provide three-dimensional volumetric information about oral and maxillofacial structures. It involves having an X-ray source and detector simultaneously rotate 360 degrees around the patient's head, which is fixed and stabilised. This is then used to generate multi-planar three-dimensional volume data set to provide diagnostic images. Compared to conventional

\section{Correspondence address:}

Faisal Khosa, Department of Emergency and Trauma Radiology, Vancouver General Hospital, Jim Patterson South, 899 West 12 ${ }^{\text {th }}$ Avenue, G861,

Vancouver V5Z 1M9, BC, Canada, e-mail: fkhosa@hotmail.com

Authors' contribution:

A Study design · B Data collection · C Statistical analysis · D Data interpretation - E Manuscript preparation · F Literature search · G Funds collection 
CT, CBCT has numerous benefits including reduced radiation dose, improved image accuracy, and superior image resolution [1]. For these reasons, it has been used for various applications including assessment of tooth root morphology $[2,3]$, pathology and resorption of temporomandibular joint (TMJ) disorders [4], implant correlation to anatomical structures [5], periapical lesions [6], and endodontics [7]. Because of the varied clinical applications of oral and maxillofacial CBCT, it is important to survey the existing literature and study the trends of this progressive field.

Bibliometrics utilises statistical analysis to examine the effectiveness and efficiency of peer-reviewed research [8]. Citation analysis, a frequently used method, analyses publications by their citation counts and reflects the impact and quality of the top articles [9]. In spite of some limitations, citation analysis remains an important method to assess publications that have made a significant impact on a particular field [10]. The two most widely used bibliometric databases are Thomas Reuter's Web of Science, which provides coverage of 12,000 journals, and Scopus, covering over 22,000 journals and proceeding volumes [11].

Although there are several bibliometric analyses published in the field of dentistry and radiology [12-20], no bibliometric studies have been published on the topic of oral and maxillofacial CBCT, which is the premise of our study.

\section{Material and methods}

A database of the most-influential publications on the topic of oral and maxillofacial CBCT was generated using Thomas Reuter's Web of Science and Elsevier's Scopus. All journals were included regardless of their field of specialty, language, country of origin, or electronic availability of the abstract.

We used key terms for 1) cone-beam computed tomography (CBCT), 2) oral and maxillofacial pathologies, and 3) oral and maxillofacial anatomical structures.

The terms were combined in the following format:

1. (Cone-beam CT OR CBCT OR Cone-beam Computed Tomography OR C-arm CT OR Flat Panel CT OR Digital Volume Tomography OR DVT OR Compact CT OR Compact Computed Tomography OR Volumetric CT OR Volumetric Computed Tomography OR Ortho cubic); AND

2. (Osteonecrosis OR Osteoporosis OR Impacted Teeth OR Supernumerary Teeth OR Dental Fractures OR Maxillary Sinus OR Surgery OR Mandibular Canals OR Endodontic Lesions OR Jaw deformities OR Orthodontics OR Reconstructions OR Surgery OR Trauma OR Airway OR Apical Periodontitis);

AND

3. (Maxillofacial OR Craniofacial OR Dental OR Jaw OR Mandible OR Maxilla OR Oral OR Tooth OR Teeth OR Nasopalatine Canal OR Temporomandibular Joint OR TMJ).
A total of 4953 publications resulted from these search terms with publication dates ranging from 1975 to 2016 . The publications were arranged by their total citation counts, in descending order. One board-certified radiologist and one board-certified dentist screened the 321 top-cited manuscripts for inclusion of the publications that discussed the clinical applications of oral and maxillofacial CBCT. Publications that used reconstruction models, extracted teeth, phantom models, or human cadavers were excluded. Additionally, those that were not related to oral and maxillofacial CBCT, explored basic science research, or did not include human subjects were excluded. Meta-analyses, reviews, letters, editorial, and communication and case reports were also excluded.

From the 321 most cited articles, 50 publications were chosen based on the above inclusion and exclusion criteria and compiled into the database. This is a sufficient sample size, which allowed us to identify the common characteristics of the most cited articles.

Citation counts from Scopus, Web of Science, and Web of Science Core Collection were collected and crosschecked. Final citation counts reported in our manuscript were taken from Thomas Reuter's Web of Science.

Using the method described by Lim et al. [21], we collected the following data: article title, WOS all database citations, WOS Core Collection citations, Scopus citations, year, journal of publication, authors, number of authors, number of institutions, country of primary institution, study design, sample size, and imaged structures.

We reported continuous variables using mean, median, and range. Categorical variables were analysed by frequency and percentage. SPSS 20 was used to summarise the data.

\section{Results}

The list of top 50 articles, their total citation counts, and citations per year were taken from Thomson Reuter's Web of Science. This was cross-matched with the list generated by the same search terms using Elsevier's Scopus. The top articles are listed in Table 1.

\section{Citations (total and citations per year)}

The top 50 publications were cited between 43 and 170 times, with a median of 55.5 citations. On an annual basis, they were cited between 2.6 and 17 times, with a median of 7.1 citations per year. The top three publications by total citations were: 1) "Limited cone-beam CT and intraoral radiography for the diagnosis of periapical pathology", with 170 citations, 2) "Accuracy of cone beam computed tomography and panoramic and periapical radiography for detection of apical periodontitis", with 144 citations, and 3) "A clinical study of changes in the volume of bone grafts in the atrophic maxilla”, with 120 citations. After adjustments were made for the number of citations per year, the top two articles remained in the same order, with 17.0 and 
Table 1. Top 50 most cited articles in the field of oral and maxillofacial cone-beam computed tomography, ranked in descending order, first by total citations, then by citations per year

\begin{tabular}{|c|c|c|c|}
\hline Rank & Article title & $\begin{array}{l}\text { Total } \\
\text { citation counts }\end{array}$ & $\begin{array}{l}\text { Citations } \\
\text { per year }\end{array}$ \\
\hline 1 & $\begin{array}{l}\text { Lofthag-Hansen S, Huumonen S, Grondahl K, Grondahl HG. Limited cone-beam CT and intraoral radio- } \\
\text { graphy for the diagnosis of periapical pathology. Oral Surg Oral Med Oral Pathol Oral Radiol Endod 2007; } \\
\text { 103: 114-119 }\end{array}$ & 170 & 17 \\
\hline 2 & $\begin{array}{l}\text { Estrela C, Bueno MR, Leles CR et al. Accuracy of cone beam computed tomography and panoramic and } \\
\text { periapical radiography for detection of apical periodontitis. J Endod 2008; 34:273-279 }\end{array}$ & 144 & 16 \\
\hline 3 & $\begin{array}{l}\text { Johansson B, Grepe A, Wannfors K, Hirsch JM. A clinical study of changes in the volume of bone grafts in the } \\
\text { atrophic maxilla. Dentomaxillofac Radiol 2001; 30: 157-161 }\end{array}$ & 120 & 7.5 \\
\hline 4 & $\begin{array}{l}\text { Walker L, Enciso R, Mah J. Three-dimensional localization of maxillary canines with cone-beam computed } \\
\text { tomography. Am J Orthod Dentofacial Orthop 2005; 128: 418-423 }\end{array}$ & 119 & 9.9 \\
\hline 5 & $\begin{array}{l}\text { Aboudara C, Nielsen I, Huang JC et al. Comparison of airway space with conventional lateral headfilms and } \\
\text { 3-dimensional reconstruction from cone-beam computed tomography. Am J Orthod Dentofacial Orthop } \\
\text { 2009; 135: 468-479 }\end{array}$ & 101 & 12.6 \\
\hline 6 & $\begin{array}{l}\text { Tantanapornkul W, Okouchi K, Fujiwara Y et al. A comparative study of cone-beam computed tomography } \\
\text { and conventional panoramic radiography in assessing the topographic relationship between the mandibu- } \\
\text { lar canal and impacted third molars. Oral Surg Oral Med Oral Pathol Oral Radiol Endod 2007; 103: 253-259 }\end{array}$ & 97 & 9.7 \\
\hline 7 & $\begin{array}{l}\text { Holberg C, Steinhauser S, Geis P, Rudzki-Janson I Cone-beam computed tomography in orthodontics: } \\
\text { benefits and limitations. J Orofac Orthop 2005; 66: 434-444 }\end{array}$ & 94 & 7.8 \\
\hline 8 & $\begin{array}{l}\text { Low KM, Dula K, Burgin W, von Arx T. Comparison of periapical radiography and limited cone-beam tomo- } \\
\text { graphy in posterior maxillary teeth referred for apical surgery. J Endod 2008; 34: 557-562 }\end{array}$ & 88 & 9.8 \\
\hline 9 & $\begin{array}{l}\text { Simon JH, Enciso R, Malfaz JM et al. Differential diagnosis of large periapical lesions using cone-beam } \\
\text { computed tomography measurements and biopsy. J Endod 2006; 32: 833-837 }\end{array}$ & 84 & 7.6 \\
\hline 10 & $\begin{array}{l}\text { Cevidanes LH, Bailey LJ, Tucker SF et al. Three-dimensional cone-beam computed tomography for assessment } \\
\text { of mandibular changes after orthognathic surgery. Am J Orthod Dentofacial Orthop 2007; 131: } 44-50\end{array}$ & 81 & 8.1 \\
\hline 11 & $\begin{array}{l}\text { Maki K, Inou N, Takanishi A, Miller AJ. Computer-assisted simulations in orthodontic diagnosis and } \\
\text { the application of a new cone beam X-ray computed tomography. Orthod Craniofac Res 2003; } 6 \text { (Suppl. 1): } \\
\text { 95-101; discussion 79-82 }\end{array}$ & 81 & 5.8 \\
\hline 12 & $\begin{array}{l}\text { Hamada Y, Kondoh T, Noguchi K et al. Application of limited cone beam computed tomography to clinical } \\
\text { assessment of alveolar bone grafting: A preliminary report. Cleft Palate Craniofac J 2005; 42: 128-137 }\end{array}$ & 78 & 9.8 \\
\hline 13 & $\begin{array}{l}\text { de Oliveira AE, Cevidanes LH, Phillips C et al. Observer reliability of three-dimensional cephalometric lan- } \\
\text { dmark identification on cone-beam computerized tomography. Oral Surg Oral Med Oral Pathol Oral Radiol } \\
\text { Endod 2009; 107: 256-265 }\end{array}$ & 78 & 6.5 \\
\hline 14 & $\begin{array}{l}\text { Estrela C, Bueno MR, Azevedo BC et al. A new periapical index based on cone beam computed tomography. } \\
\text { J Endod 2008; 34: 1325-1331 }\end{array}$ & 76 & 8.4 \\
\hline 15 & $\begin{array}{l}\text { Aboudara CA, Hatcher D, Nielsen IL, Miller A. A three-dimensional evaluation of the upper airway in adole- } \\
\text { scents. Orthod Craniofac Res 2003; } 6 \text { (Suppl 1): 173-175 }\end{array}$ & 75 & 5.4 \\
\hline 16 & $\begin{array}{l}\text { Vannier MW, Hildebolt CF, Marsh JL et al. Craniosynostosis: Diagnostic value of three-dimensional CT recon- } \\
\text { struction. Radiology 1989; 173:669-673 }\end{array}$ & 73 & 2.6 \\
\hline 17 & $\begin{array}{l}\text { Liu DG, Zhang WL, Zhang ZY et al. Localization of impacted maxillary canines and observation of adjacent } \\
\text { incisor resorption with cone-beam computed tomography. Oral Surg Oral Med Oral Pathol Oral Radiol Endod } \\
\text { 2008; 105: 91-98 }\end{array}$ & 70 & 7.8 \\
\hline 18 & $\begin{array}{l}\text { Grauer D, Cevidanes LS, Styner MA et al. Pharyngeal airway volume and shape from cone-beam computed } \\
\text { tomography: relationship to facial morphology. Am J Orthod Dentofacial Orthop 2009; 136: 805-814 }\end{array}$ & 68 & 8.5 \\
\hline 19 & $\begin{array}{l}\text { Angelopoulos C, Thomas SL, Hechler S et al. Comparison between digital panoramic radiography and } \\
\text { cone-beam computed tomography for the identification of the mandibular canal as part of presurgical } \\
\text { dental implant assessment. J Oral Maxillofac Surg 2008; } 66: 2130-2135\end{array}$ & 67 & 7.4 \\
\hline 20 & $\begin{array}{l}\text { Ludlow JB, Gubler M, Cevidanes L, Mol A. Precision of cephalometric landmark identification: cone-beam } \\
\text { computed tomography vs. conventional cephalometric views. Am J Orthod Dentofacial Orthop 2009; 136: } \\
312 \text { e1-10; discussion } 313\end{array}$ & 66 & 8.3 \\
\hline
\end{tabular}


Table 1. Cont

\begin{tabular}{|c|c|c|c|}
\hline Rank & Article title & $\begin{array}{l}\text { Total } \\
\text { citation counts }\end{array}$ & $\begin{array}{l}\text { Citations } \\
\text { per year }\end{array}$ \\
\hline 21 & $\begin{array}{l}\text { Bernardes RA, de Moraes IG, Hungaro Duarte MA et al. Use of cone-beam volumetric tomography in the } \\
\text { diagnosis of root fractures. Oral Surg Oral Med Oral Pathol Oral Radiol Endod 2009; 108: 270-277 }\end{array}$ & 64 & 8 \\
\hline 22 & $\begin{array}{l}\text { Mazor Z, Horowitz RA, Del Corso M et al. Sinus floor augmentation with simultaneous implant placement } \\
\text { using Choukroun's platelet-rich fibrin as the sole grafting material: A radiologic and histologic study } \\
\text { at } 6 \text { months. J Periodontol 2009; 80: 2056-2064 }\end{array}$ & 63 & 7.9 \\
\hline 23 & $\begin{array}{l}\text { Alexiou K, Stamatakis H, Tsiklakis K. Evaluation of the severity of temporomandibular joint osteoarthritic } \\
\text { changes related to age using cone beam computed tomography. Dentomaxillofac Radiol 2009; 38: 141-147 }\end{array}$ & 62 & 7.8 \\
\hline 24 & $\begin{array}{l}\text { Rungcharassaeng K, Caruso JM, Kan JY et al. Factors affecting buccal bone changes of maxillary posterior } \\
\text { teeth after rapid maxillary expansion. Am J Orthod Dentofacial Orthop 2007; 132: 428e1-8 }\end{array}$ & 57 & 5.7 \\
\hline 25 & $\begin{array}{l}\text { Swennen GR, Mommaerts MY, Abeloos J et al. A cone-beam CT based technique to augment the 3D virtual } \\
\text { skull model with a detailed dental surface. Int J Oral Maxillofac Surg 2009; 38: 48-57 }\end{array}$ & 56 & 7 \\
\hline 26 & $\begin{array}{l}\text { Cha JY, Mah J, Sinclair P. Incidental findings in the maxillofacial area with 3-dimensional cone-beam ima- } \\
\text { ging. Am J Orthod Dentofacial Orthop 2007; 132: 7-14 }\end{array}$ & 55 & 5.5 \\
\hline 27 & $\begin{array}{l}\text { Tai CC, Sutherland IS, McFadden L. Prospective analysis of secondary alveolar bone grafting using computed } \\
\text { tomography. J Oral Maxillofac Surg 2000; 58: 1241-1249; discussion } 1250\end{array}$ & 55 & 3.2 \\
\hline 28 & $\begin{array}{l}\text { Arisan V, Karabuda ZC, Ozdemir T. Accuracy of two stereolithographic guide systems for computer-aided } \\
\text { implant placement: a computed tomography-based clinical comparative study. J Periodontol 2010; 81: } \\
\text { 43-51 }\end{array}$ & 53 & 7.6 \\
\hline 29 & $\begin{array}{l}\text { Dudic A, Giannopoulou C, Leuzinger M, Kiliaridis S. Detection of apical root resorption after orthodontic } \\
\text { treatment by using panoramic radiography and cone-beam computed tomography of super-high resolu- } \\
\text { tion. Am J Orthod Dentofacial Orthop 2009; 135: 434-437 }\end{array}$ & 53 & 6.6 \\
\hline 30 & $\begin{array}{l}\text { Ghaeminia H, Meijer GJ, Soehardi A et al. Position of the impacted third molar in relation to the mandibular } \\
\text { canal. Diagnostic accuracy of cone beam computed tomography compared with panoramic radiography. } \\
\text { Int J Oral Maxillofac Surg 2009; 38: 964-971 }\end{array}$ & 52 & 6.5 \\
\hline 31 & $\begin{array}{l}\text { Nakagawa Y, Ishii H, Nomura Y et al. Third molar position: Reliability of panoramic radiography. J Oral } \\
\text { Maxillofac Surg 2007; 65: 1303-1308 }\end{array}$ & 52 & 5.2 \\
\hline 32 & $\begin{array}{l}\text { Rigolone M, Pasqualini D, Bianchi L et al. Vestibular surgical access to the palatine root of the superior } \\
\text { first molar: „low-dose cone-beam“ CT analysis of the pathway and its anatomic variations. J Endod 2003; 29: } \\
773-775\end{array}$ & 52 & 3.7 \\
\hline 33 & $\begin{array}{l}\text { Garrett BJ, Caruso JM, Rungcharassaeng K et al. Skeletal effects to the maxilla after rapid maxillary expan- } \\
\text { sion assessed with cone-beam computed tomography. Am J Orthod Dentofacial Orthop 2008; 134: 8-9 }\end{array}$ & 51 & 5.7 \\
\hline 34 & $\begin{array}{l}\text { Lenza MG, Lenza MM, Dalstra M et al. An analysis of different approaches to the assessment of upper airway } \\
\text { morphology: A CBCT study. Orthod Craniofac Res 2010; 13: 96-105 }\end{array}$ & 50 & 7.1 \\
\hline 35 & $\begin{array}{l}\text { Haney E, Gansky SA, Lee JS et al. Comparative analysis of traditional radiographs and cone-beam computed } \\
\text { tomography volumetric images in the diagnosis and treatment planning of maxillary impacted canines. } \\
\text { Am J Orthod Dentofacial Orthop 2010; 137: 590-597 }\end{array}$ & 50 & 7.1 \\
\hline 36 & $\begin{array}{l}\text { Kirmeier R, Payer M, Wehrschuetz M et al. Evaluation of three-dimensional changes after sinus floor aug- } \\
\text { mentation with different grafting materials. Clin Oral Implants Res 2008; 19:366-372 }\end{array}$ & 50 & 5.6 \\
\hline 37 & $\begin{array}{l}\text { Zhang R, Yang H, Yu X et al. Use of CBCT to identify the morphology of maxillary permanent molar teeth in } \\
\text { a Chinese subpopulation. Int Endod J 2011; 44: 162-169 }\end{array}$ & 49 & 8.2 \\
\hline 38 & $\begin{array}{l}\text { Estrela C, Bueno MR, De Alencar AH et al. Method to evaluate inflammatory root resorption by using cone } \\
\text { beam computed tomography. J Endod 2009; 35: 1491-1497 }\end{array}$ & 49 & 6.1 \\
\hline 39 & $\begin{array}{l}\text { Pohlenz P, Blessmann M, Blake F, Heinrich S et al. Clinical indications and perspectives for intraoperative } \\
\text { cone-beam computed tomography in oral and maxillofacial surgery. Oral Surg Oral Med Oral Pathol Oral } \\
\text { Radiol Endod 2007; 103: 412-417 }\end{array}$ & 49 & 4.9 \\
\hline 40 & $\begin{array}{l}\text { Iwasaki T, Hayasaki H, Takemoto Y et al. Oropharyngeal airway in children with Class III malocclusion } \\
\text { evaluated by cone-beam computed tomography. Am J Orthod Dentofacial Orthop 2009; 136: } 318 \text { e1-9; } \\
\text { discussion } 319\end{array}$ & 48 & 6 \\
\hline
\end{tabular}


Table 1. Cont

\begin{tabular}{|c|c|c|c|}
\hline Rank & Article title & $\begin{array}{l}\text { Total } \\
\text { citation counts }\end{array}$ & $\begin{array}{l}\text { Citations } \\
\text { per year }\end{array}$ \\
\hline 41 & $\begin{array}{l}\text { Edlund M, Nair MK, Nair UP. Detection of vertical root fractures by using cone-beam computed tomography: } \\
\text { a clinical study. J Endod 2011; 37: 768-772 }\end{array}$ & 47 & 7.8 \\
\hline 42 & $\begin{array}{l}\text { Nickenig HJ, Eitner S. Reliability of implant placement after virtual planning of implant positions using cone } \\
\text { beam CT data and surgical (guide) templates. J Craniomaxillofac Surg 2007; 35: 207-211 }\end{array}$ & 47 & 5.9 \\
\hline 43 & $\begin{array}{l}\text { Tso HH, Lee JS, Huang JC et al. Evaluation of the human airway using cone-beam computerized tomography. } \\
\text { Oral Surg Oral Med Oral Pathol Oral Radiol Endod 2009; 108: 768-776 }\end{array}$ & 47 & 4.7 \\
\hline 44 & $\begin{array}{l}\text { Cevidanes LH, Hajati AK, Paniagua B et al. Quantification of condylar resorption in temporomandibular joint } \\
\text { osteoarthritis. Oral Surg Oral Med Oral Pathol Oral Radiol Endod 2010; 110: 110-117 }\end{array}$ & 45 & 6.4 \\
\hline 45 & $\begin{array}{l}\text { Hassan B, Couto Souza } P \text {, Jacobs R et al. Influence of scanning and reconstruction parameters on quality of } \\
\text { three-dimensional surface models of the dental arches from cone beam computed tomography. Clin Oral } \\
\text { Investig 2010; 14:303-310 }\end{array}$ & 45 & 6.4 \\
\hline 46 & $\begin{array}{l}\text { Maal TJ, Plooij JM, Rangel FA et al. The accuracy of matching three-dimensional photographs with skin } \\
\text { surfaces derived from cone-beam computed tomography. Int J Oral Maxillofac Surg 2008; 37: 641-646 }\end{array}$ & 45 & 5 \\
\hline 47 & $\begin{array}{l}\text { Botticelli S, Verna C, Cattaneo PM et al. Two- versus three-dimensional imaging in subjects with unerupted } \\
\text { maxillary canines. Eur J Orthod 2011; 33: 344-349 }\end{array}$ & 44 & 7.2 \\
\hline 48 & $\begin{array}{l}\text { Bornstein MM, Lauber R, Sendi P, von Arx T. Comparison of periapical radiography and limited cone-beam } \\
\text { computed tomography in mandibular molars for analysis of anatomical landmarks before apical surgery. } \\
\text { J Endod 2011;37: 151-157 }\end{array}$ & 43 & 7.3 \\
\hline 49 & $\begin{array}{l}\text { Kim SH, Choi YS, Hwang EH et al. Surgical positioning of orthodontic mini-implants with guides fabricated } \\
\text { on models replicated with cone-beam computed tomography. Am J Orthod Dentofacial Orthop 2007; } 131 \\
\text { (4 Suppl): S82-89 }\end{array}$ & 43 & 4.3 \\
\hline 50 & $\begin{array}{l}\text { Heiland M, Schulze D, Blake F, Schmelzle R. Intraoperative imaging of zygomaticomaxillary complex fractu- } \\
\text { res using a 3D C-arm system. Int J Oral Maxillofac Surg 2005; 34:369-375 }\end{array}$ & 43 & 3.6 \\
\hline
\end{tabular}

16.0 citations per year, respectively. However, "Comparison of airway space with conventional lateral head films and 3-dimensional reconstruction from cone-beam computed tomography", with 12.6 citations per year, became the third most-cited article on an annual basis.

\section{Year of publication}

The year of publication of top-cited publications ranged from 1989 to 2011. All, except for one paper, were published after the year 2000. Figure 1 shows a graphical distribution of the top-cited publications.

\section{Number of authors}

The articles had an average of five authors. The most prolific authors are Cevidanes, Lucia Helena S. and Miller, Arthur J., who each had five publications. Cevidanes, Lucia Helena S. had two first authorships and Miller, Arthur J. had three last authorships. The top authors in the field are summarised in Table 2.

\section{Country of origin}

The United States of America contributed 15 of the highly cited publications to the field of oral and maxillofacial CBCT. This was followed by Brazil, and Japan, which contributed six

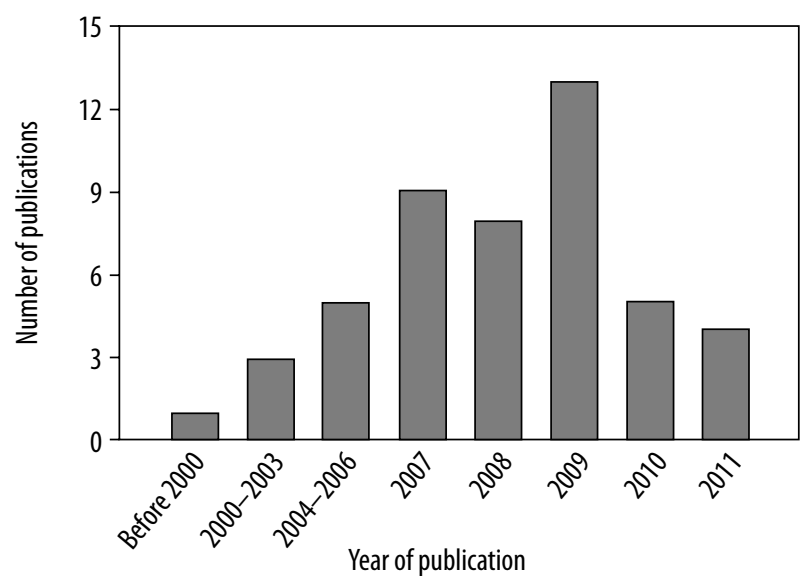

Figure 1. Distribution of the top 50 articles in oral and maxillofacial conebeam computed tomography by year of publication

and five publications, respectively. The countries that contributed two or more publications are summarised in Table 3.

\section{Journals of publication}

The 50 most-cited articles were published across 17 different journals. The top journals were American Journal of Orthodontics and Dentofacial Orthopedics $(n=12)$, Journal of Endodontics $(n=8)$, and Oral Surgery, Oral Medicine, Oral Pathology, Oral Radiology and Endodontology $(n=8)$. 
Table 2. Most prolific authors in oral and maxillofacial cone-beam computed tomography

\begin{tabular}{|c|c|c|c|c|l|}
\hline Author & $\begin{array}{c}\text { Total } \\
\text { number }\end{array}$ & $\begin{array}{c}\text { First } \\
\text { author }\end{array}$ & $\begin{array}{c}\text { Last } \\
\text { author }\end{array}$ & $\begin{array}{c}\text { Other } \\
\text { authors }\end{array}$ & Current institution of affiliation \\
\hline $\begin{array}{c}\text { Cevidanes, } \\
\text { Lucia Helena S. }\end{array}$ & 5 & 2 & 0 & 3 & $\begin{array}{l}\text { UNC School of Dentistry, Department of Orthodontics, } 201 \text { Brauer Hall, } \\
\text { UNC School of Dentistry, Chapel Hill, NC, USA }\end{array}$ \\
\hline Miller, Arthur J. & 5 & 0 & 3 & 2 & $\begin{array}{l}\text { Division of Orthodontics, Department of Orofacial Sciences, School of Dentistry, } \\
\text { University of California at San Francisco, San Francisco, CA, USA. }\end{array}$ \\
\hline $\begin{array}{c}\text { Azevedo, Bruno } \\
\text { Correa }\end{array}$ & 4 & 0 & 0 & 4 & Department of Dental Diagnostic Science, University of Texas, San Antonio, Texas \\
\hline Maki, Koutaro & 4 & 1 & 0 & 3 & Department of Orthodontics, Showa University, Tokyo, Japan \\
\hline Bueno, Mike Reis & 3 & 0 & 0 & 3 & Department of Semiology and Stomatology, University of Cuiabá, Cuiabá, MT, Brazil \\
\hline Estrela, Carlos & 3 & 3 & 0 & 0 & Federal University of Goiás, Goiânia, G0, Brazil \\
\hline Hatcher, David & 3 & 0 & 1 & 2 & $\begin{array}{l}\text { Department of Growth and Development, University of California, } \\
\text { Division of Orthodontics, San Francisco, CA, USA }\end{array}$ \\
\hline Huang, John C. & 3 & 0 & 1 & 2 & $\begin{array}{l}\text { Division of Orthodontics, Department of Orofacial Sciences, School of Dentistry, } \\
\text { University of California, San Francisco, California }\end{array}$ \\
\hline Phillips, Ceib L. & 3 & 0 & 1 & 2 & $\begin{array}{l}\text { Department of Orthodontics, University of North Carolina, Chapel Hill, } \\
\text { North Carolina, USA }\end{array}$ \\
\hline Styner, Martin A. & 3 & 0 & 0 & 3 & $\begin{array}{l}\text { Department of Computer Science, School of Arts and Sciences, } \\
\text { University of North Carolina, Chapel Hill, North Caroline, USA }\end{array}$ \\
\hline
\end{tabular}

Table 3. The most productive countries in oral and maxillofacial cone-beam computed tomography (only countries with two or more publications are shown)

\begin{tabular}{|c|c|}
\hline Country of origin & Number of publications \\
\hline USA & 15 \\
\hline Brazil & 6 \\
\hline Japan & 5 \\
\hline Germany & 4 \\
\hline Switzerland & 3 \\
\hline Netherlands & 3 \\
\hline Sweden & 2 \\
\hline China & 2 \\
\hline
\end{tabular}

Table 4 shows the journals with two or more publications and their impact factors.

\section{Additional descriptors}

We also analysed the manuscripts based on their study designs (prospective or retrospective), number of affiliated institutions, sample sizes, and primary imaged structures. This information is summarised in Table 5.

\section{Discussion}

We identified the top 50 cited articles in the field of oral and maxillofacial CBCT. Out of the 50 articles, the only article published before 2000 was "Craniosynostosis: diagnostic value of three-dimensional CT reconstruction".

Table 4. Top journals in oral and maxillofacial cone-beam computed tomography (only journals with two or more publications are shown)

\begin{tabular}{|l|c|c|}
\hline Journal of publication & Number of publications & 5-tear Impact Factor (2011-2016) \\
\hline American Journal of Orthodontics and Dentofacial Orthopedics & 12 & 1.382 \\
\hline Journal of Endodontics & 8 & 3.375 \\
\hline Oral Surgery Oral Medicine Oral Pathology Oral Radiology and Endodontology & 8 & 1.644 \\
\hline International Journal of Oral and Maxillofacial Surgery & 4 & 1.92 \\
\hline Journal of Oral and Maxillofacial Surgery & 3 & 1.785 \\
\hline Orthodontics \& Craniofacial Research & 3 & 1.64 \\
\hline Journal of Periodontology & 2 & 2.706 \\
\hline Dentomaxillofacial Radiology & 2 & 1.919 \\
\hline
\end{tabular}


This article, by Vannier et al., was published in Radiology in 1989. This shows that CBCT is a rapidly expanding field of imaging that has only recently been utilised for clinical practice. The top three articles identified by citation per year compared the utility between oral and maxillofacial CBCT to radiographs in the diagnosis of periapical lesions, apical periodontitis, and nasopharyngeal airway restriction, respectively [22-24]. The third most cited article by total citation counts, "A clinical study of changes in the volume of bone grafts in the atrophic maxilla", by Johansson et al., published in Dentomaxillofacial Radiology in 2001, examined volumetric changes associated with bone grafts.

The articles were affiliated with an average of 5.24 authors and 3.7 institutions, and most of the articles $(n=30)$ had three or more affiliated institutions. This shows that there is much collaboration in the field. Most of the articles $(n=38)$ had a patient sample size of less than 100 , indicating that larger sample size is not necessarily correlated with success. Most of the studies $(n=42)$ were prospective. Although the majority of the studies $(n=27)$ imaged primary tooth pathologies, there were also a significant number of articles that discussed imaging of bone grafts or dental implants ( $n$ $=7)$, upper airways $(n=5)$, the skull $(n=4)$, and other maxillofacial structures $(n=7)$. Thus, it can be seen that oral and maxillofacial CBCT has a wide array of clinical applications.

The top three journals were American Journal of Orthodontics and Dentofacial Orthopedics $(n=12)$, Journal of Endodontics $(n=8)$, and Oral Surgery, Oral Medicine, Oral Pathology, Oral Radiology, and Endodontics $(n=8)$. There is healthy competition amongst the different countries in this research field. The United States of America $(n=15)$ was the most productive country, followed by Brazil $(n=6)$ and Japan $(n=5)$. Importantly, Sweden $(n=2)$ contributed two of the three most cited articles.

Identification of top articles by their citation counts is a relatively good measure of academic success but this approach also has its limitations. The first is the "obliteration by incorporation" phenomenon, which occurs when the information becomes common knowledge so that the landmark articles are rarely cited [25]. Because CBCT is a relatively new technology, we suppose that this phenomenon did not significantly affect our study. The second limitation is that publications from earlier years were more likely to appear in our database because they have had more time since publication and were thus more likely to be cited. For example, the third most cited article in our database, "A clinical study of changes in the volume of bone grafts in the atrophic maxilla", published in 2001, had a total citation count of 120 (7.5 citations per year), while the fifth most cited article, "Comparison of airway space with conventional lateral head films and 3-dimensional reconstruction from cone-beam computed tomography", published in 2009, had 12.6 citations per year with a total citation count of 101 . In addition, our database did not include articles published after 2011 because these articles did not have enough time to accumulate an adequate
Table 5. Study designs, number of affiliated institutions, sample sizes, and imaged structures of the top 50 articles in oral and maxillofacial conebeam computed tomography

\begin{tabular}{|c|c|c|}
\hline Category & Descriptors & $\begin{array}{c}\text { Number } \\
\text { of publications }\end{array}$ \\
\hline \multirow[t]{2}{*}{ Study design } & Prospective & $42(84 \%)$ \\
\hline & Retrospective & $8(16 \%)$ \\
\hline \multirow{5}{*}{$\begin{array}{l}\text { Number } \\
\text { of affiliated } \\
\text { institutions }\end{array}$} & One & $10(20 \%)$ \\
\hline & Two & $9(18 \%)$ \\
\hline & Three to four & $10(20 \%)$ \\
\hline & Five to six & $15(30 \%)$ \\
\hline & Seven or more & $5(10 \%)$ \\
\hline \multirow[t]{7}{*}{ Sample sizes } & 10 to 19 & $14(28 \%)$ \\
\hline & 20 to 29 & $8(16 \%)$ \\
\hline & 30 to 39 & $6(12 \%)$ \\
\hline & 40 to 49 & $4(8 \%)$ \\
\hline & 50 to 99 & $6(12 \%)$ \\
\hline & $100+$ & $10(20 \%)$ \\
\hline & Not specified & $2(4 \%)$ \\
\hline \multirow{5}{*}{$\begin{array}{l}\text { Imaged } \\
\text { structures }\end{array}$} & Teeth & $27(54 \%)$ \\
\hline & Bone grafts/implants & $7(14 \%)$ \\
\hline & Upper airways & $5(10 \%)$ \\
\hline & Skull & $4(8 \%)$ \\
\hline & Other maxillofacial structures & $7(14 \%)$ \\
\hline
\end{tabular}

number of citations. Because the research field is still in its infancy, it would be valuable to re-examine the literature after a few years to identify the top-cited publications.

Self-citation is another limitation of citation analysis. Previous research indicates that self-citations do not significantly influence research [26]. However, it may play a role in our bibliometric analysis because each article had five authors on average. Furthermore, open-access articles may be able to acquire more citations because they are available without subscription [27]. However, in our bibliometric analysis, open-access articles did not play a major role because only five of the top 50 articles were available via open access. This is probably because most academic researchers would likely have access to institution-based journal subscription services and be able to access information found in these articles. Lastly, we only considered articles that were published in peer-reviewed academic research journals in our study. Thus, we did not include "grey literature" such as opinion or positional papers, government documents, or conference proceedings.

Furthermore, Scopus, Web of Science, and Google Scholar generated different citation counts. Web of Science was used for this study because it was the most consistent with our search criteria. Lastly, we found many irrelevant publications in our initial search - these were filtered out after discussion with a team of three independent reviewers. 


\section{Conclusions}

The use of CBCT for oral and maxillofacial applications is a relatively novel concept that only emerged in the beginning of the 21st century. Since then, it has been studied in a variety of applications including imaging of primary tooth pathologies, upper airways, the skull, and other maxillofacial structures. Currently, most of the original clinical research in this area is conducted in a prospective multi-institutional approach involving small sample sizes (fewer than 100 patients). However, given the rapid growth in this area, it would be valuable to reassess the trends in a few years. Our study identifies the characteristics of successful literature in the field of cone-beam oral and maxillofacial computed tomography. This information is important for academic dentists to gain valuable insights regarding the trends that are steering the field of oral and maxillofacial CBCT and thus publish effectively in the future.

\section{Conflict of interest and sources of funding statement}

Dr. Khosa is the recipient of the Canadian Association of Radiologists/Canadian Radiological Foundation Leadership Scholarship (2017). The authors have no relevant disclosures and no conflicts of interest. There was no commercial funding for this study.

\section{References}

1. Scarfe WC, Farman AG, Sukovic P. Clinical applications of conebeam computed tomography in dental practice. J Can Dent Assoc 2006; 72: 75-80.

2. Alrahabi M, Sohail Zafar M. Evaluation of root canal morphology of maxillary molars using cone beam computed tomography. Pak J Med Sci 2015; 31: 426-430.

3. Zafar M, Alrahabi M. Cone beam computed tomography for exploring morphology of mandibular first molar. Br J Med Med Res 2015; 6: 514-521.

4. Larheim TA, Abrahamsson AK, Kristensen M, et al. Temporomandibular joint diagnostics using CBCT. Dentomaxillofac Radiol 2015; 44: 20140235

5. Gupta J, Ali SP. Cone beam computed tomography in oral implants. Natl J Maxillofac Surg 2013; 4: 2-6.

6. de Paula-Silva FW, Wu MK, Leonardo MR, et al. Accuracy of periapical radiography and cone-beam computed tomography scans in diagnosing apical periodontitis using histopathological findings as a gold standard. J Endod 2009; 35: 1009-1012.

7. Kapila S, Conley RS, Harrell WE. The current status of cone beam computed tomography imaging in orthodontics. Dentomaxillofac Radiol 2011; 40: 24-34.

8. Garfield E. Citation analysis as a tool in journal evaluation. Science 1972; 178: 471-479.

9. Choudhri AF, Siddiqui A, Khan NR, et al. Understanding bibliometric parameters and analysis. Radiographics 2015; 35: 736-746.

10. Moed HF. The impact-factors debate: the ISI's uses and limits. Nature 2002; 415: 731-732.

11. Tripathy P, Tripathy PK. Chapter 19: Scopus' Journal Analyzer: Helps Librarians and Researchers Determine Who's Best. Fundamentals of Research: A Dissective Review. Diplomica Publishing GmbH, Hamburg 2015; 188-192.

12. Jayaratne YS, Zwahlen RA. The evolution of dental journals from 2003 to 2012: A bibliometric analysis. PLoS One 2015; 10: e0119503.

13. Jain S, Basavaraj P, Singla A, et al. Bibliometric analysis of journal of clinical and diagnostic research (dentistry section; 2007-2014). J Clin Diagn Res 2015; 9: ZC47-51.

14. Kolahi J, Khazaei S. Altmetric: Top 50 dental articles in 2014. Br Dent J 2016; 220: 569-574.
15. Dolan RS, Hanna TN, Warraich GJ, et al. The top 100 articles in the radiology of trauma: a bibliometric analysis. Emerg Radiol 2015; 22: 667-675.

16. Pagni M, Khan NR, Cohen HL, et al. Highly cited works in radiology: The top 100 cited articles in radiologic journals. Acad Radiol 2014; 21: 1056-1066.

17. O'Keeffe ME, Hanna TN, Holmes D, et al. The 100 most-cited original articles in cardiac computed tomography: A bibliometric analysis. J Cardiovasc Comput Tomogr 2016; 10: 414-423.

18. Khan MS, Ullah W, Riaz IB, et al. Top 100 cited articles in cardiovascular magnetic resonance: a bibliometric analysis. J Cardiovasc Magn Reson 2016; 18 : 87.

19. Shahzeb Khan M, Fatima K, Bin Riaz I, et al. The 20 most-cited articles in echocardiography literature. Eur Heart J 2017; 38: 74-78.

20. Siddiqi TJ, Usman MS, Khan MS, et al. The 100 most influential papers in the field of thrombolytic therapy: A bibliometric analysis. Am J Cardiovasc Drugs 2017; 17: 319-333.

21. Lim KJ, Yoon DY, Yun EJ, et al. Characteristics and trends of radiology research: A survey of original articles published in AJR and Radiology between 2001 and 2010. Radiology 2012; 264: 796-802.

22. Lofthag-Hansen S, Huumonen S, Gröndahl K, et al. Limited conebeam CT and intraoral radiography for the diagnosis of periapical pathology. Oral Surg Oral Med Oral Pathol Oral Radiol Endod 2007; 103: 114-119.

23. Estrela C, Bueno MR, Leles CR, et al. Accuracy of cone beam computed tomography and panoramic and periapical radiography for detection of apical periodontitis. J Endod 2008; 34: 273-279.

24. Aboudara C, Nielsen I, Huang JC, et al. Comparison of airway space with conventional lateral headfilms and 3-dimensional reconstruction from cone-beam computed tomography. Am J Orthod Dentofacial Orthop 2009; 135: 468-479.

25. Seglen PO. Citation rates and journal impact factors are not suitable for evaluation of research. Acta Orthop Scand 1998; 69: 224-229.

26. Swanson EW, Miller DT, Susarla SM, et al. What effect does self-citation have on bibliometric measures in academic plastic surgery? Ann Plast Surg 2016; 77: 350-353.

27. Eysenbach G. Citation advantage of open access articles. PLoS Biol 2006; 4: e157. 